\title{
Minimal dose of a stimulus for maximal pepsin secretion
}

\author{
H. G. DesaI \\ M.D., Ph.D.
}

\author{
M. P. ZAVERI \\ B.Sc.
}

\author{
F. P. Antia \\ M.D., M.S., F.R.C.P. \\ Pai Department of Gastroenterology, B. Y. L. Nair Charitable Hospital, \\ Dr A. L. Nair Road, Bombay 8
}

\begin{abstract}
Summary
Dose-response curves were obtained with subcutaneous histamine acid phosphate (HAP) in twenty-two subjects, intravenous HAP in fifteen subjects, subcutaneous pentagastrin in fourteen subjects and intravenous pentagastrin in twelve subjects in order to determine the minimal doses of these stimuli for maximal pepsin secretion.

The minimal doses for maximal pepsin secretion were $2.8 \mathrm{mg}$ HAP on SHT, $1.2 \mathrm{mg} / \mathrm{hr}$ HAP on IHT, $300 \mu \mathrm{g}$ pentagastrin on SPT and $100 \mu \mathrm{g} / \mathrm{hr}$ pentagastrin on IPT.
\end{abstract}

From dose-response curves, the minimal doses for maximal acid secretion were reported for subcutaneous (Kay, 1953) or intravenous (Lawrie, Smith \& Forrest, 1964) histamine acid phosphate (HAP) and subcutaneous (Makhlouf, McManus \& Card, 1966) or intravenous (Konturek \& Lankosz, 1967) pentagastrin (ICI 50123). However, similar dose-response curves to determine the minimal dose of a stimulus for maximal pepsin secretion are not reported. In various studies, the doses of different stimuli which had caused a maximal acid secretion were administered to stimulate maximal pepsin secretion, on the assumption that parietal and chief cells have some definite relationship both in health and disease in all individuals.

The object of this study was to perform doseresponse curves with different stimuli with a view to determine the minimal doses for maximal pepsin secretion.

\section{Materials and methods}

Dose response curves were performed with subcutaneous HAP in doses of $1 \cdot 6,2 \cdot 0,2 \cdot 4,2 \cdot 8$ and $3 \cdot 2$ $\mathrm{mg}$ in twenty-three male subjects (eleven control and twelve duodenal ulcer), with intravenous HAP in doses of $0.8,1.2,1.6,2.0,2.4$ and $2.8 \mathrm{mg} / \mathrm{hr}$ in fifteen male subjects (nine control and six duodenal ulcer), with subcutaneous pentagastrin in doses of
$250,300,350,400$ and $450 \mu \mathrm{g}$ in fifteen male subjects (four control and eleven duodenal ulcer) and with intravenous pentagastrin in doses of $50,100,150$ and $200 \mu \mathrm{g} / \mathrm{hr}$ in twelve male subjects (four control and eight duodenal ulcer).

Gastric aspirate was obtained through 14 or $16 \mathrm{Fr}$ Levine tube by continuous hand suction for $1 \mathrm{hr}$ during subcutaneous tests and for $2 \mathrm{hr}$ during intravenous tests. Details of the procedure are given in a previous study (Desai, Zaveri \& Antia, 1970a). Pepsin estimation was performed in each half-hour sample by the method of Hunt (Hunt, 1948) using plasma as substrate; the blue colour with Folin and Ciocalteu reagent was measured on a colorimeter. In our laboratory, $1 \mathrm{mg}$ of crystalline pepsin (Worthington Biochemical, USA) showed 140 Hunt units of peptic activity.

\section{Results}

Subcutaneous histamine tests (SHT)

On increasing the doses of HAP from 1.6 to 2.0 , 2.0 to 2.4 and 2.4 to $2.8 \mathrm{mg}$, the mean and standard deviation (SD) of differences of pepsin output on paired ' $t$ ' testing showed an increase of $1.8 \pm 1.8$ $(P<0.01), 1.46 \pm 1.6(P<0.01)$ and $1.46 \pm 2.56$ $(P<0.05)$ kilounits/hr respectively. Further increase in dosage of HAP from $2 \cdot 8$ to $3 \cdot 2 \mathrm{mg}$ showed a significant decrease of $1.38 \pm 2.5$ kilounits/hr of pepsin output $(P<0.05)$ (Table 1$)$. The minimal dose of

TABLE 1. Dose-response curves on subcutaneous histamine test in twenty-two subjects for pepsin estimation

\begin{tabular}{lcccccc}
\hline & \multicolumn{5}{c}{ Dose of subcutaneous HAP (mg) } \\
\cline { 2 - 6 } & 1.6 & 2.0 & 2.4 & 2.8 & 3.2 \\
\hline Mean and SD & 1.8 & 1.46 & 1.46 & -1.38 \\
of differences & \pm & \pm & \pm & \pm & \\
of pepsin & 1.8 & 1.6 & 2.56 & 2.5 \\
output & $(18) *$ & $(19)$ & $(18)$ & $(18)$ \\
(Kilounits/hr) & $<0.01$ & $<0.01$ & $<0.05$ & $<0.05$ \\
$P$ & &
\end{tabular}

* The figures in brackets refer to paired ' $t$ ' test in each group (Tables 1-4). 
subcutaneous HAP for maximal pepsin secretion was $2.8 \mathrm{mg}$. A supramaximal dose of $3.2 \mathrm{mg}$ caused a significant reduction of pepsin output.

\section{Intravenous histamine tests (IHT)}

On increasing the doses of intravenous HAP from 0.8 to $1.2,1.2$ to 1.6 and 1.6 to $2.0 \mathrm{mg} / \mathrm{hr}$, the mean and SD of differences of pepsin output on paired ' $t$ ' testing showed an increase of $2 \cdot 14 \pm 2 \cdot 76(P=0.05)$, $0.22 \pm 1.95(P>0.05)$ and $0.24 \pm 2.27(P>0.05)$ kilourits/30 min respectively. Further increase in dosage of HAP from 2.0 to 2.4 and 2.4 to $2.8 \mathrm{mg} / \mathrm{hr}$ showed a reduction of $0.61 \pm 1.93(P>0.05)$ and $1.23 \pm 1.17(P<0.01)$ kilounits $/ 30$ min respectively (Table 2). The minimal dose of intravenous HAP for maximal pepsin secretion was $1.2 \mathrm{mg} / \mathrm{hr}$ while a supramaximal dose of $2.8 \mathrm{mg} / \mathrm{hr}$ caused a significant reduction of pepsin output.

\section{Subcutaneous pentagastrin tests (SPT)}

On increasing the doses of pentagastrin from 250 to 300 and 300 to $350 \mu \mathrm{g}$, the mean and SD of differences of pepsin output showed an increase of $2.11 \pm 2.77(P=0.05)$ and $0.11 \pm 4.57(P>0.05)$ kilounits/hr respectively. Further increase in dosage from 350 to 400 and 400 to $450 \mu \mathrm{g}$ caused a reduction of pepsin output of $0.52 \pm 4.28(P>0.05)$ and 0.58 $\pm 2.73(P>0.05)$ kilounits $/ \mathrm{hr}$ respectively (Table 3$)$. The reduction of pepsin output $(1.94 \pm 5.15$ kilounits/hr) on increasing the dose from 350 to $450 \mu \mathrm{g}$ was also not significant $(P>0 \cdot 05)$. The minimal dose of subcutaneous pentagastrin for maximal pepsin secretion was $300 \mu \mathrm{g}$.

\section{Intravenous pentagastrin tests (IPT)}

On increasing the doses of pentagastrin from 50 to $100 \mu \mathrm{g} / \mathrm{hr}$ and 100 to $150 \mu \mathrm{g} / \mathrm{hr}$, the mean and SD of differences of pepsin output showed a rise of 0.93 $\pm 1.24(P<0.05)$ and $0.63 \pm 1.36(P>0.05)$ kilounits/30 min respectively. Further increase of dosage from 150 to $200 \mu \mathrm{g} / \mathrm{hr}$ caused a reduction of $0.35 \pm$ $1.86(P>0.05)$ kilounits/30 min (Table 4). The minimal dose of intravenous pentagastrin for maximal pepsin secretion was $100 \mu \mathrm{g} / \mathrm{hr}$.

\section{Discussion}

Dose-response curves for maximal pepsin secretion have been obtained with subcutaneous pentagastrin in two control subjects (Makhlouf et al., 1966) and with intravenous pentagastrin and histamine in three control subjects (Berstad \& Patersen, 1971) but the minimal doses for maximal pepsin secretion were not obvious as only a few subjects were studied. In the present study, the minimal doses for maximal pepsin secretion were $2.8 \mathrm{mg}$ HAP on SHT, $1.2 \mathrm{mg} / \mathrm{hr}$ HAP on IHT, $300 \mu \mathrm{g}$ pentagastrin on SPT and $100 \mu \mathrm{g} / \mathrm{hr}$ pentagastrin on IPT. The results showed that the minimal subcutaneous doses for maximal pepsin secretion were identical with these reported for maximal acid secretion (Desai $e t$

TABLE 2. Dose-response curves on intravenous histamine test in fifteen subjects for pepsin estimation

\begin{tabular}{|c|c|c|c|c|c|c|}
\hline & \multicolumn{6}{|c|}{ Dose of intravenous histamine $(\mathrm{mg} / \mathrm{hr})$} \\
\hline & 0.8 & $1 \cdot 2$ & $1 \cdot 6$ & $2 \cdot 0$ & $2 \cdot 4$ & $2 \cdot 8$ \\
\hline $\begin{array}{l}\text { Mean and SD } \\
\text { of differences } \\
\text { of pepsin output } \\
\text { (Kilounits/30 } \\
\text { min) }\end{array}$ & $\begin{array}{c}2 \cdot 14 \\
\pm \\
2 \cdot 76 \\
(8)^{*}\end{array}$ & $\begin{array}{c}0.22 \\
\pm \\
1.95 \\
(12)\end{array}$ & $\begin{array}{c}0.24 \\
\pm \\
2 \cdot 27 \\
(8)\end{array}$ & $\begin{array}{c}-0.61 \\
\pm \\
1.93 \\
(10)\end{array}$ & $\begin{array}{c}-1 \cdot 23 \\
\pm \\
1 \cdot 17 \\
(11)\end{array}$ & \\
\hline$P$ & $=0.05$ & $>0.05$ & $>0.05$ & $>0.05$ & $<0.01$ & \\
\hline
\end{tabular}

* The figures in brackets refer to paired ' $t$ ' test in each group.

TABLE 3. Dose-response curves with subcutaneous pentagastrin in fourteen subjects for pepsin estimation

\begin{tabular}{|c|c|c|c|c|c|}
\hline & \multicolumn{5}{|c|}{ Dose of subcutaneous pentagastrin $(\mu \mathrm{g})$} \\
\hline & 250 & 300 & 350 & 400 & 450 \\
\hline $\begin{array}{l}\text { Mean and SD } \\
\text { of differences } \\
\text { of pepsin }\end{array}$ & $\begin{array}{c}2 \cdot 11 \\
\pm\end{array}$ & $\begin{array}{c}0 \cdot 11 \\
\pm\end{array}$ & $\begin{array}{c}-0.52 \\
\pm\end{array}$ & & \\
\hline $\begin{array}{l}\text { output } \\
\text { (Kilounits/hr) }\end{array}$ & $\begin{array}{l}2 \cdot 77 \\
(9)\end{array}$ & $\begin{array}{l}4 \cdot 57 \\
(10)\end{array}$ & $\begin{array}{l}4 \cdot 28 \\
(12)\end{array}$ & & \\
\hline$P$ & $=0.05$ & $>0.05$ & $>0.05$ & & \\
\hline
\end{tabular}

* The figures in brackets refer to paired ' $t$ ' test in each group.
TABLE 4. Dose-response curves with intravenous pentagastrin test in twelve subjects for pepsin estimation

Dose of intravenous pentagastrin $(\mu \mathrm{g} / \mathrm{hr})$

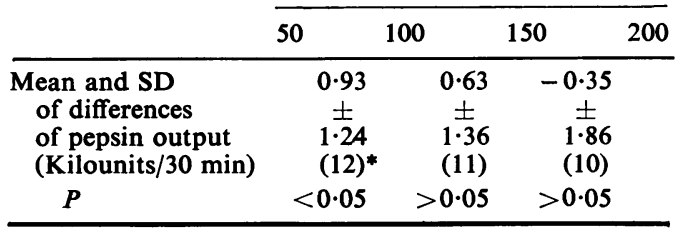

* The figures in brackets refer to paired ' $t$ ' test in each group. 
TABLE 5. Comparison of values of maximal pepsin secretion with subcutaneous or intravenous histamine and pentagastrin in two subjects

\begin{tabular}{|c|c|c|c|c|c|c|c|c|c|c|c|c|c|c|c|c|c|}
\hline \multirow{2}{*}{ No. } & \multirow{2}{*}{ Route } & \multicolumn{7}{|c|}{ Histamine acid phosphate (mg) } & \multicolumn{9}{|c|}{ Pentagastrin $(\mu \mathrm{g})$} \\
\hline & & $0 \cdot 8$ & $1 \cdot 2$ & $1 \cdot 6$ & $2 \cdot 0$ & $2 \cdot 4$ & $2 \cdot 8$ & $3 \cdot 2$ & 50 & 100 & 150 & 200 & 250 & 300 & 350 & 400 & 450 \\
\hline \multirow[t]{2}{*}{1} & Subcutaneous & - & - & $6 \cdot 8$ & $7 \cdot 2$ & $7 \cdot 6^{*}$ & $6 \cdot 2$ & $6 \cdot 1$ & - & - & - & - & - & - & $6 \cdot 6$ & $8 \cdot 2$ & $10 \cdot 8^{*}$ \\
\hline & Intravenous & $8 \cdot 8^{*}$ & $8 \cdot 5$ & - & $7 \cdot 5$ & $7 \cdot 5$ & $7 \cdot 2$ & 一 & $5 \cdot 0$ & $5 \cdot 8$ & $7 \cdot 2^{*}$ & $5 \cdot 8$ & - & - & 一 & - & - \\
\hline \multirow[t]{2}{*}{2} & Subcutaneous & - & - & $7 \cdot 5$ & $7 \cdot 2$ & $7 \cdot 9$ & $7 \cdot 0$ & $8 \cdot 4^{*}$ & - & - & - & 一 & $8 \cdot 1$ & $9 \cdot 7$ & $9 \cdot 9 *$ & $9 \cdot 1$ & 9.9 \\
\hline & Intravenous & $5 \cdot 8$ & $5 \cdot 5$ & $7 \cdot 3$ & 8.9 & $96^{*}$ & $8 \cdot 4$ & - & $7 \cdot 3$ & $9 \cdot 0^{*}$ & $8 \cdot 6$ & $7 \cdot 8$ & - & - & - & - & - \\
\hline
\end{tabular}

* Highest value, figures in kilounits/30 min.

al., 1969; Desai, Zaveri \& Antia, 1972). However, the minimal intravenous doses for maximal pepsin secretion, $1.2 \mathrm{mg} / \mathrm{hr}$ HAP and $100 \mu \mathrm{g} / \mathrm{hr}$ pentagastrin, are smaller than those required for maximal acid secretion, $2.0 \mathrm{mg} / \mathrm{hr} \mathrm{HAP}$ and $150 \mu \mathrm{g} / \mathrm{hr}$ pentagastrin (Desai, Zaveri \& Antia, 1970b; Desai, Zaveri, Dalvi \& Antia, 1972). That minimal doses of intravenous pentagastrin and HAP for maximal pepsin secretions are lower than those for maximal acid secretion was reported by Berstad \& Patersen (1971).

Supramaximal doses of subcutaneous and intravenous HAP caused a significant partial inhibition of pepsin secretion (Tables 1 and 2). Higher doses of pentagastrin also caused reduction of pepsin secretion but the differences were not significant (Tables 3 and 4). Pepsin secretion was not reduced with intravenous pentagastrin up to $7 \mu \mathrm{g} / \mathrm{kg} / \mathrm{hr}$ (Berstad \& Patersen, 1971) but doses higher than $8 \mu \mathrm{g} / \mathrm{kg} / \mathrm{hr}$ showed a tendency to fall (Makhlouf et al., 1966).

In humans, histamine (Hirschowitz, London \& Pollard, 1957), histalog (Wormsley, Mahoney \& Ng, 1966) and pentagastrin (Makhlouf et al., 1966) stimulate pepsin secretion and values with any stimulus are comparable. In contrast, maximal values of pepsin secretion were shown to be appreciably lower with pentagastrin than histamine (Berstad \& Patersen, 1971). In the present study, the values of maximal pepsin secretion in two subjects with HAP or pentagastrin by either route were comparable (Table 5).

\section{Acknowledgments}

Part of the work was done with a grant from B. Y. L. Nair Charitable Hospital and TNMC Research Society.

\section{References}

Berstad, A. \& Patersen, H. (1971) Comparison of histamine and pentagastrin in stimulation of pepsin secretion in man. Scandinavian Journal of Gastroenterology, 6, 209.

Desai, H.G., Antia, F.P., Gupte, U.V. \& Potnis, P.R. (1969) Dose of histamine for maximal stimulation of gastric acid secretion. Modified subcutaneous histamine test. Gastroenterology, 57, 636.

Desai, H.G., ZAVERI, M.P. \& ANTIA, F.P. (1970a) Comparison of dose-response curves with subcutaneous and intravenous histamine. Gastroenterology, 59, 701.

Desai, H.G., ZaVeri, M.P. \& ANTIA, F.P. (1970b) Intravenous histamine tests with fixed doses of histamine. Minimal dose of histamine for maximal acid secretion. Scandinavian Journal of Gastroenterology, 5, 617.

Desai, H.G., Zaveri, M.P. \& ANTIA, F.P. (1972) Subcutaneous pentagastrin test with fixed doses (independent of bodyweight). Indian Journal of Medical Research, $60,378$.

Desai, H.G., Zaveri, M.P., Dalvi, H.G. \& Antia, F.P. (1972) Dose of intravenous pentagastrin for maximal acid secretion. Indian Journal of Medical Research, 60, 1164.

Hirschowitz, B.I., London, J.L. \& Pollard, H.M. (1957) Histamine stimulation of gastric pepsin secretion in man. Gastroenterology, 32, 85.

HuNT, J.N. (1948) A method for estimating peptic activity in gastric contents. Biochemical Journal, 42, 104.

KAY, A.W. (1953) Effect of large doses of histamine on gastric secretion of $\mathrm{HCl}$-an augmented histamine test. British Medical Journal, 2, 77.

Konturek, S.J. \& Lankosz, J. (1967) Pentapeptide infusion test. Scandinavian Journal of Gastroenterology, 2, 112.

LAWrie, J.H., SMith, G.M.R. \& Forrest, A.P.M. (1964) The histamine infusion test. Lancet, ii, 207.

Makhlouf, G.M., McManus, J.P.A. \& CARD, W.I. (1966) Action of pentapeptide (ICI 50123) on gastric secretion in man. Gastroenterology, 51, 455.

Wormsley, K.G., MAHONEY, M.P. \& Ng, M. (1966) Effects of a gastrin-like pentapeptide (ICI 50123) on stomach and pancreas. Lancet, i, 993. 